JINOTEP 5 (2) April (2019): 69-73

JINOTEP (Jurnal Inovasi Teknologi Pembelajaran)

Kajian dan Riset Dalam Teknologi Pembelajaran

http://journal2.um.ac.id/index.php/jinotep/index

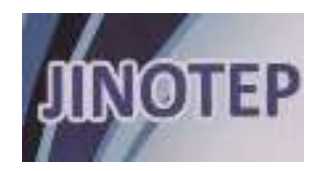

\title{
PENGEMBANGAN MULTIMEDIA PEMBELAJARAN VOCABULARY MATERI BUAH - BUAHAN BERBASIS MOBILE PADA MATA PELAJARAN BAHASA INGGRIS KELAS III SD
}

\author{
Ardiansyah Rohman, Dedi Kuswandi, Saida Ulfa
}

Universitas Negeri Malang

\section{Article History}

Received: March 21, 2019

Accepted: April 29, 2019

Published: April 30, 2019

\section{Keywords}

Development, Multimedia mobile learning, English lecture Pengembangan, Multimedia pembelajaran mobile, Bahasa Inggris

\begin{abstract}
Abstrak
Tujuan pengembangan ini adalah menghasilkan sebuah produk berupa multimedia pembelajaran berbasis mobile (m-learning) untuk smartphone Android pada mata pelajaran Bahasa Inggris kelas III pokok bahasan vocabulary buah-buahan di SD Negeri Sananwetan 1 Blitar. Media yang dikembangkan digunakan untuk pembelajaran siswa secara mandiri. Data dikumpulkan dengan menggunakan angket dari 1 ahli media, 1 ahli materi, dan 24 siswa dan dianalisis dengan teknik kuantitatif \& kualitatif. Hasil penelitian adalah multimedia dinyatakan valid untuk digunakan dengan hasil perhitungan ahli media 75\%, ahli materi 93,75\%, kepada audiens/siswa yaitu individu 94,37\% kelompok kecil 94,7\%, dan uji coba lapangan 93,3\%.

\section{Abstract}

The aim of this development is to produce a product in the form of mobile multimediabased learning (m-learning) for Android smartphones in English lecture III class subject fruits vocabulary in SD Negeri Sananwetan 1 Blitar. Developed media used for student learning independently. Data was collected using a questionnaire from one media expert, one expert matter, and 24 students and analyzed using quantitative \& qualitative techniques. The results of the study is a multimedia expressed valid for use with the calculated $75 \%$ of media experts, materials experts $93.75 \%$, to an audience / students that individual 94,37\%, small group $94.7 \%$, and $93.3 \%$ field trials.
\end{abstract}

Corresponding author :

Ardiansyah Rohman

Universitas Negeri Malang

Jalan Semarang 5 Malang

E-mail: shiivas07@gmail.com
2019 Universitas Negeri Malang p-ISSN 2406-8780 e-ISSN 2654-7953 


\section{PENDAHULUAN}

Mobile learning adalah salah satu jenis pembelajaran yang sedang berkembang saat ini. Konsep pembelajarannya sendiri mobile learning mempunyai kelebihan yang tidak dimiliki media lain yaitu mudah di akses setiap saat dan lebih menarik untuk dipelajari pada umumnya. Quinn (2000) berpendapat bahwa mlearning adalah sebuah e-learning yang dapat diwujudkan melalui perangkat mobile, namun m-learning memiliki manfaat ketersediaan materi ajar yang dapat diakses pengguna kapan saja dan di mana saja melalui perangkat mobile. Surahman (2017) berpendapat mobile learning memungkinkan pembelajaran yang dapat mempersonalisasi pebelajar melalui inovasi adaptive mobile learning .

Media yang dihasilkan bukan hanya menggunakan teks, namun juga memuat unsur-unsur yang terdapat dalam multimedia yaitu teks, audio, gambar, animasi, dan video, sehingga dapat membantu siswa dalam mengasah materi pelajaran menggunakan smartphone yang berbasis sistem operasi android. Pengertian multimedia sendiri menurut Gayeski (1993) dalam Munir (2013: 2) adalah kumpulan media berbasis computer dan sistem komunikasi yang memiliki peran untuk membangun, menyimpan, menghantarkan dan menerima informasi dalam bentuk teks, grafik, audio, video dan sebaginya.

Tingkat perkembangan perangkat mobile yang sangat tinggi, tingkat penggunaan yang relatif mudah, dan harga perangkat yang semakin terjangkau merupakan faktor pendorong yang semakin memperluas kesempatan penerapan m-learning sebagai alternatif baru dalam belajar, yang membentuk paradigma bahwa belajar dapat dilakukan kapan saja dan di mana saja (Darmawan, 2013:15).

Bahasa inggris sebagai bahasa asing yang dianggap penting diajarkan untuk tujuan penyerapan dan pengembangan hubungan antar bangsa. Dalam pembelajaran Bahasa Inggris mencakup empat keterampilan berbahasa, yaitu berbicara, mendengarkan, membaca dan menulis..

Penguasaan kosa kata (vocabulary) dalam suatu bahasa tertentu keberadaannya sangat penting. Arti penting penguasaan kosa kata dapat dilihat dalam pernyataan Valerre (1977) dalam Ferry (2008) yaitu: (1) Kemampuan untuk mengerti makna bahasa tergantung pada satu pengetahuan kosa kata. (2) Kosa kata merupakan aspek pentung dalam ketrampilan berbahasa. (3) Kemampuan menulis bahasa asing didukung dalam pengetahuan leksikal suatu bahasa.

Berdasarkan sumber-sumber diatas, diperlukan adanya sarana pembantu belajar siswa dengan mengikuti perkembangan teknologi sekarang ini. Multimedia pembelajaran berbasis mobile menjadi salah satu terobosan baru dalam dunia pendidikan, dan juga mudah digunakan siswa kapanpun dan dimanapun. Materi vocabulary pada siswa kelas III SD memerlukan suatu media untuk mempermudah pemahaman, karena kata-kata nya sering dijumpai pada kehidupan sehari-hari. Sehingga siswa perlu media yang menarik untuk dipahami. Pengembangan multimedia yang dibuat oleh penulis ini berbasis mobile diharapkan mampu memfasilitasi kebutuhan siswa dalam mempelajari vocabulary materi buah-buahan.

\section{METODE}

Metode yang digunakan pada penelitian ini adalah pendekatan penelitian pengembangan Research and Development (R\&D) yang dikembangkan oleh Borg and Gall (1989) dalam (Sukmandinata, 2008), yaitu: (1) penelitian dan pengumpulan data, (2) perencanaan pengembangan produk, (3) pengembangan produk awal, (4) uji coba produk awal, (5) penyempurnaan produk awal, (6) uji coba produk yang telah disempurnakan, (7) penyempurnaan produk dan pengujian produk, (8) produk akhir dan implementasi produk.

Dalam Penelitian dan pengumpulan data ini peneliti akan menggunakan teknik pengumpulan data seperti observasi lapangan yang mengidentifikasi potensi berupa wawancara, literatur yang berupa teori, dan kuisoner yang akan dilakukan oleh responden.

Perancanaan pengembangan produk yang diharapkan akan dapat meningkatkan efektifitas proses pembelajaran dalam kelas yang membantu siswa mempermudah 
memahami materi. Setelah proses penelitian dan pengembangan didapat berupa sebuah desain produk baru, yang disertai spesifikasinya. Dalam proses selanjutnya pengembang akan membuat sampel awal multimedia pembelajaran berbasis mobile yang akan dikembangkan setelah melalui tahap perencanaan awal.

Setelah produk dihasilkan dan dilakukan proses pengembangan produk awal akan diuji coba. Pengujian dilakukan ke ahli media, ahli materi, dan beberapa siswa untuk melihat hasil uji individu dan hasil uji kelompok kecil, peneliti sendiri melakukan 4 sampel siswa untuk menguji kelayakan multimedia untuk suatu pembelajaran individu

Pengujian produk pada sampel yang terbatas dapat menunjukkan sistem pembelajaran yang baru lebih efektif. Dalam proses uji coba kemunginan penyempurnaan produk seperlunya untuk meningkatkan efisiensi dalam pembelajaran. Revisi produk dilakukan dengan menganalisis kekurangan yang ditemui, kemudian segera melakukan perbaikan terhadap produk..

Setelah melakukan revisi produk, maka produk m-learning diterapkan dalam kondisi lingkup yang lebih luas. Dalam proses ini peneliti melakukan pengujian kelompok besar yang terdiri dari 20 sampel siswa. M-learning tersebut, tetap diperlukan penilaian untuk perbaikan lanjut.

Revisi produk dilakukan setelah didapatkan penilaian dari uji coba pemakaian, dimana terdapat kekurangan dalam uji coba, maka pengembang perlu melakukan pembenahan dalam produk yang dikembangkan. Setelah itu pembuatan produk masal dilakukan apabila produk yang diuji coba dinyatakan efektif dan layak diproduksi masal

Dalam melakukan penelitian, peneliti menggunakan instrumen berupa angket. Subyek penelitian dalam uji coba pengembangan ini adalah siswa kelas III SD Negeri Sananwetan 1 Blitar. Jenis data yang digunakan adalah kuantitatif dan kualitatif. Perlu diketahui bahwa dalam penelitian yang dilakukan penulis hanya menguji validitas media saja, dikarenakan keterbatasan waktu penulis untuk melakukan penelitian lapangan

\section{HASIL DAN PEMBAHASAN}

Berdasarkan tahap validasi desain dan uji coba produk, diperoleh data berupa hasi validasi yang ditunjukkan pada Tabel 1 di bawah ini.

\section{Tabel 1 Data Validasi}

\begin{tabular}{clll}
\hline No & Responden & Presentase & Kriteria \\
\hline 1 & Ahli Media & $75 \%$ & $\begin{array}{l}\text { Cukup } \\
\text { Valid }\end{array}$ \\
2 & Ahli Materi & $93,75 \%$ & Valid \\
3 & Individu & $94.37 \%$ & Valid \\
4 & $\begin{array}{l}\text { Kelompok } \\
\text { Kecil }\end{array}$ & $94,7 \%$ & Valid \\
5 & $\begin{array}{l}\text { Kelompok } \\
\text { Besar }\end{array}$ & $93,3 \%$ & Valid \\
\hline
\end{tabular}

Berdasarkan analisis data dan saran yang diberikan oleh ahli media yang berisi kesesuaian multimedia, interface multimedia, kemenarikan multimedia, kombinasi warna, ketepatan tata letak, ketepatan alur, kemenarikan dan interaktifitas multimedia. Secara keseluruhan media yang telah dikembangkan telah memenuhi kualifikasi valid untuk dijadikan media pembelajaran siswa secara mandiri dengan presentasi $75 \%$. Berdasarkan instrumen angket yang telah diberikan kepada ahli media, maka diperoleh tanggapan bahwa multimedia pembelajaran mobile yang telah dikembangkan sudah bagus namun perlu pengembangan dalam audio.

Berdasarkan analisis data dan saran yang diberikan oleh ahli materi yang berisi kejelasan judul, tingkat kemenarikan multimedia, tujuan pembelajaran, kesesuaian materi dengan SK dan KD, keterkaitan dengan pembelajaran sebelumnya, urutan materi, bahasa yang digunakan, tata letak gambar, kemenarikan kalimat dalam multimedia, kelengkapan materi, mampu atau tidaknya multimedia sebagai pembelajaran mandiri, dan kemudahan penggunaan. Secara keseluruhan media yang telah dikembangkan telah memenuhi kualifikasi valid untuk dijadikan media pembelajaran siswa secara mandiri dengan presentasi 93,75\%. Berdasarkan instrumen angket yang telah diberikan kepada ahli materi, maka diperoleh tanggapan secara garis besar siswa dapat menggunakan multimedia ini untuk sarana belajar. 
72 JINOTEP (Jurnal Inovasi dan Teknologi Pembelajaran) Kajian dan Riset dalam Teknologi Pembelajaran Vol. 5, No. 2, April 2019, Hal. 69-73

Berdasarkan analisis data dan saran yang diberikan oleh siswa, yang terbagi menjadi 3 kelompok yaitu individu, kelompok kecil dan kelompok besar. Dimana dalam bagian individu lebih ditekankan pada pokok-pokok penting yang dibahas dalam multimedia pembelajaran, kelompok kecil lebih ditekankan dalam interface multimedia, sedangkan kelompok besar lebih ke seluruh pembahasan yang ada dalam multimedia pembelajaran. Dalam uji individu diperoleh hasil 94,37 menyatakan media valid, dalam uji kelompok kecil diperoleh hasil 94,7 menyatakan valid, dan dalam uji kelompok besar diperoleh hasil 93,3\% menyatakan valid, dari ketiga hasil diatas diambil kesimpulan bahwa multimedia yang diteliti peneliti memperoleh hasil valid. Berdasarkan angket yang telah diberikan kepada siswa maka diperoleh tanggapan sebagai berikut:

a) Penambahan gambar diperbesar.

b) Penambahan materi agar lebih lengkap.

c) Ukuran tombol diperbesar lagi karena terlalu kecil bila media dijalankan pada smartphone Android dengan layar 4 inchi.

Pembelajaran bergerak atau mobile learning merupakan salah satu inovasi media pembelajaran era digital. Mobile learning memudahkan pebelajar untuk dapat mengakses materi dari mana pun dan kapan pun. Mobile learning melatihan kontrol diri yang baik pada pebelajar. Untuk melatihan hal tersebut perlu diberikan kesadaran yang baik dalam praktik belajar mandiri. Mobile learning yang baik perlu memenuhi prinsipprinsip multimedia sebagaimana jenid multimedia lainnya (Surahman, 2017).

Untuk mendapatkan hasil pengukuran hasil belajar yang baik, maka guru perlu memilih model evaluasi yang sesuai dengan model dan pendekatan pembelajaran yang dilakukan. Surahman (2018) berpendapat bahwa salah satu model evaluasi yang cocok digunakan dalam proses pembelajaran era digital adalah Model Peer Collaborative Authentic Assessment (PECOLASE). Model tersebut memiliki keunggulan dalam mengoptimalkan potensi peserta didik dalam proses pemberian umpan balik khususnya dalam konteks pembelajaran berbasis karya siswa.

\section{SIMPULAN DAN SARAN}

Ada beberapa alas an perangkat mobile dipilih sebaga media pembelajaran, antara lain: 1) Penetrasi perangkat mobile sangat cepat;2) Jumlah perangkat mobile lebih banyak dibandingkan computer; 3) Lebih mudah dioperasikan daripada computer; 4) Perangkat mobile dapat dipakai sebagai media pembelajaran (Darmawan, 2913: 15).

Dari hasil uji coba yang dilakukan peneliti pada kelompok besar yang terdiri dari 20 siswa, dapat disimpulkan bahwa media yang dikembangkan telah memenuhi kriteria valid, yaitu dengan prosentase mencapai 93,3\%. Mengenai tampilan dan desain media, mayoritas siswa berpendapat bahwa media yang dikembangkan menarik. Konten gambar yang disajikan berdampingan dengan teks penjelasan memudahkan siswa dalam mempelajari materi.

Sebagian siswa merasa dengan adanya media ini cukup mampu untuk memfasilitasi kebutuhan belajar siswa secara mandiri. Kalimat-kalimat pada teks penjelasan juga perlu dibuat lebih komunikatif untuk menarik minat siswa. Pada aspek tombol, sebagian siswa merasa tombol yang digunakan terlalu kecil jika diakses melalui smartphone dengan layar 4 inchi.

\section{Saran}

Saran untuk diseminasi produk ke sasaran yang lebih luas dengan cara mengupload media ke Google Play Store. Google Play Store merupakan layanan konten digital milik Google di mana pengguna smartphone Android dapat mengunduh berbagai aplikasi sesuai yang diinginkannya.

Pengembangaan produk lebih lanjut yaitu dengan menambah grafik/animasi bergerak untuk menambah daya tarik media, penambahan materi agar lebih lengkap, serta perbaikan pada tombol agar memudahkan pengguna untuk mengontrol media.

\section{DAFTAR RUJUKAN}

Darmawan, Deni. 2013. Teknologi Pembelajaran. Bandung: PT Remaja Rosdakarya

Darsono. 2002. Theori Pembelajaran. Jakarta: Erlangga

Munir. 2013. Multimedia: Konsep \& Aplikasi dalam Pendidikan. Bandung: Alfabeta 
Quinn, C. (2000). mLearning: Mobile, wireless, inyour-pocket learning. LiNE Zine, 2006, 1-2.

Sukmadinata, nana Syaodih. 2008. Metode Penelitian Pendidikan. Bandung: PT Remaja Rosdakarya

Sulistiyono, F. D. (2010). Efektivitas pemanfaatan model animasi pembelajaran dalam penguasaan vocabulary untuk siswa kelas IV semester II SDN Bajang 01 Kabupaten Blitar (Doctoral dissertation, Universitas Negeri Malang).

Surahman, E., \& Surjono, H. D. (2017). Pengembangan adaptive mobile learning pada mata pelajaran biologi SMA sebagai upaya mendukung proses blended learning. Jurnal Inovasi Teknologi Pendidikan, 4(1), 26-37.
Surahman, E., \& Alfindasari, D. (2017, September). Developing adaptive mobile learning with the principle of coherence Mayer on biology subjects of high school to support the open and distance education. In $3 r d$ International Conference on Education and Training (ICET 2017) (pp. 184-190). Atlantis Press.

Surahman, E., Wedi, A., Soepriyanto, Y., \& Setyosari, P. (2018, December). Design of Peer Collaborative Authentic Assessment Model Based on Group Project Based Learning to Train Higher Order Thinking Skills of Students. In International Conference on Education and Technology (ICET 2018) (pp. 75-78). Atlantis Press. 